\title{
Will Maize-Based Cropping Systems Reduce Water Consumption without Compromise of Food Security in the North China Plain?
}

\author{
Jia Yang, Jixiao Cui, Ziqin Lv, Mengmeng Ran, Beibei Sun, Peng Sui and Yuanquan Chen * \\ College of Agronomy and Biotechnology, China Agricultural University, Beijing 100193, China; \\ jiayang@alu.cau.edu.cn (J.Y.); cuijixiao@cau.edu.cn (J.C.); lzq859@163.com (Z.L.); wyxyrmm@126.com (M.R.); \\ 15600913658@163.com (B.S.); suipeng@cau.edu.cn (P.S.) \\ * Correspondence: chenyq@cau.edu.cn
}

Received: 6 September 2020; Accepted: 1 October 2020; Published: 21 October 2020

\begin{abstract}
The winter wheat-summer maize double cropping system caused overexploitation of groundwater in the North China Plain; it is unsustainable and threatens food security and the overall wellbeing of humankind in the region. Finding water-saving cropping systems without compromising food security is a more likely solution. In this study, six alternative cropping systems' water conservation and food supply capacity were compared simultaneously. A combined water footprint method was applied to analyze the cropping systems' water consumption. The winter wheat-summer maize system had the largest water consumption $\left(16,585 \mathrm{~m}^{3} /\right.$ ha on average), followed by the potato/spring maize, spinach-spring maize, rye-spring maize, vetch-spring maize, pea/spring maize, soybean||spring maize and mono-spring maize cropping systems. For the groundwater, the spinach-spring maize, pea/spring maize, soybean||spring maize systems showed a higher degree of synchronization between crop growth period and rainfall, which could reduce use of groundwater by $36.8 \%, 54.4 \%$ and $57.6 \%$, respectively. For food supply capacity, the values for spinach-spring maize, pea/spring maize, soybean||spring maize systems were $73.0 \%, 60.8 \%$ and $48.4 \%$ of winter wheat-summer maize, respectively, but they showed a better feeding efficiency than the winter wheat-summer maize system. On the whole, spinach-spring maize may be a good option to prevent further decline in groundwater level and to ensure food security in a sustainable way.
\end{abstract}

Keywords: water footprint; life cycle assessment; water saving; food security; cropping system

\section{Introduction}

The overexploitation of freshwater resources threatens food security and the overall wellbeing of humankind in many parts of the world [1]. That many studies have increased the understanding of current water scarcity [2-6], the future increasing of population pressure [7], and change of water consumption behavior [8] and climate [9], may exacerbate this unsustainable status. In China, the severe consequences of overexploitation of groundwater have shown in the North China Plain (NCP), where more than 300 million people live. In the past 50 years, the annual decrease in the groundwater reserve in the NCP was 4.8 billion cubic meters, and the cumulative decrease reached 220 billion cubic meters [10]. Moreover, groundwater overexploitation has caused river dry-up, lake shrinkage, aquifer depletion, and land subsidence in many areas [11,12]. During the last 10 years, the maximum depth of the shallow groundwater depression area increased from $52 \mathrm{~m}$ to $70 \mathrm{~m}$, and the water table in the deep groundwater cone center dropped to $100 \mathrm{~m}$ below the surface in 2013 [13].

It was grain production that had mainly led to the overexploitation of groundwater. The NCP produces over $60 \%$ of the national wheat and approximately $45 \%$ of the maize [14]. The corresponding 
agricultural use also accounts for $75 \%$ of the total water consumption [15]. Reducing water use without compromising food security is an important issue that China is facing. The dominant cropping system of the NCP is the winter wheat-summer maize double cropping system and its planting area exceeds $70 \%$ of the region's total arable area [16]. According to the research in [17], the water consumption of winter wheat was 192.6-290.1 mm, while the rainfall could only meet $17.2 \%$ (average) of its water demand; the water consumption of summer maize was $145.2-334.0 \mathrm{~mm}$, and the rainfall satisfaction rate was $77.6 \%$ (average). This means that winter wheat relies much more on groundwater irrigation to achieve ideal yield, gradually causing the excessive groundwater exploitation in the NCP.

Previous researchers [18-20], in order to relieve water shortage in the NCP, proposed a water-saving irrigation scheme for the winter wheat-summer maize cropping system. However, even with optimized irrigation, the water demand of winter wheat remained high, because the asynchronization between the rainy season and wheat growing season had not been fixed. Liang et al. [21] showed that the groundwater level would stop decreasing when the current planting area of winter wheat decreased by $76 \%$, while the annual crop production may decrease by $27 \%$. Hence, replacing a high groundwater-consuming cropping system with other alternative cropping systems is more likely to be a solution to the water scarcity of the NCP. In new cropping systems, the crop water requirement should be better coupled with rain while the yield is promising [22-24].

The spring maize mono-cropping system is a promising one which is mentioned in previous studies. Studies have confirmed that the contribution of the spring maize mono-cropping system in environmental benefits compared with the winter wheat-summer maize system, especially in water utilization $[25,26]$. At the same time, the yield of the spring maize mono-cropping system would reduce $24.4-45.8 \%$ (according to different irrigation measures) than that of the winter wheat-summer maize system [26]. In addition, the crop growing period of the mono-cropping system was apparently shorter than that of the double cropping system; the fallow period that was more than half a year and that would cause low utilization efficiency of solar-thermal resources. Nevertheless, further studies showed that the development of multiple cropping systems which combined another matched crop with spring maize was expected to make up for the shortage of the mono-cropping system in terms of economic yield and resource utilization [27-32]. However, the exact water-saving potential of new multiple cropping systems need to be re-evaluated under a standard frame.

Water footprint, as a comprehensive evaluation method for the volume of water that human activities consume and pollute, has become the forefront of international water management study. In terms of agriculture, the structure of water consumption in the crop production process can be clarified through water footprint, which will be of great value and significance to study regional water shortage in order to allocate and use water resources effectively.

The water footprint was the amount of water consumed during crop growing and the volume needed to restore water quality after having been polluted along the production process, namely the sum of green water, blue water and grey water [33]. To our knowledge, most studies of the water footprint of agricultural products were conducted according to this method [34-37]. According to the proportion of blue and green water, we could clearly understand whether the crop growth could be coupled with the precipitation period under local climate in order to reduce groundwater irrigation, which was of great significance to the North China Plain.

However, the previous studies which used water footprint were mainly focusing on agricultural products rather than cropping systems [38]. In this study, the object of our evaluation was the multiple cropping system, including rotation cropping, relay cropping and inter-cropping. Different from calculating the water footprint of a single crop, the multiple cropping system involved the problems of time, space and multiple crops, which necessitated consideration of the relationship between crops and the things included in the system. In order to conduct a more comprehensive comparison of cropping systems, we added the water consumption of the fallow period between the former and later crop, and the water consumption of agricultural material production by involving the life cycle assessment (LCA) concept to form a new calculation framework with water footprint. The combination of these 
indicators may provide a much wider view for us to understand water consumption in multiple cropping systems.

This study: (1) calculates the water consumption of multiple cropping systems by a combined calculation method, (2) analyzes the water consumption, environmental impact and food supply capacity of selected cropping systems, (3) tries to figure out whether maize-based cropping systems can reduce water consumption without compromise of food security in the North China Plain or not.

\section{Materials and Methods}

\subsection{Experimental Design and Field Management}

We intended to analyze the water consumption and food supply capacity of multiple cropping systems per hectare and per year (a completed planting year), respectively. The experiment adopted a randomized complete block design of multiple cropping systems. Rye (Secale cereal L.), spinach (Spinacia oleracea L.), vetch (Vicia villosa Roth.), potato (Solanum tuberosum L.), pea (Pisum sativum L.) and soybean (Glycine max (Linn.) Merr.), those crops with wide planting area and strong adaptability in the North China Plain, were selected to form rotation cropping, relay cropping and intercropping systems with spring maize (Zea mays L.). They were the rye-spring maize rotation cropping system, spinach-spring maize rotation cropping system, vetch-spring maize rotation cropping system, potato/spring maize relay cropping system, pea/spring maize relay cropping system and soybean||spring maize intercropping system. The winter wheat (Triticum aestivum L.)- summer maize (Zea mays L.) double cropping system and spring maize (Zea mays L.) mono-cropping system were the controls. There were 8 different treatments (including controls), and each treatment was repeated three times. Thus, there were 24 plots in total. Each plot area was $63 \mathrm{~m}^{2}(7 \mathrm{~m} \times 9 \mathrm{~m})$. The experiment record started in October 2015, and lasted for 3 years, namely the 2016 planting year (October 2015-September 2016), 2017 planting year (October 2016-September 2017), and 2018 planting year (October 2017-September 2018). Due to the weather, there might be a slight change in seeding date. The vetch was subject to broadcast sowing at the same time as rye, spinach and winter wheat. More specific field management information is available in previous research [39]. The crop growing periods are shown in Figure 1.

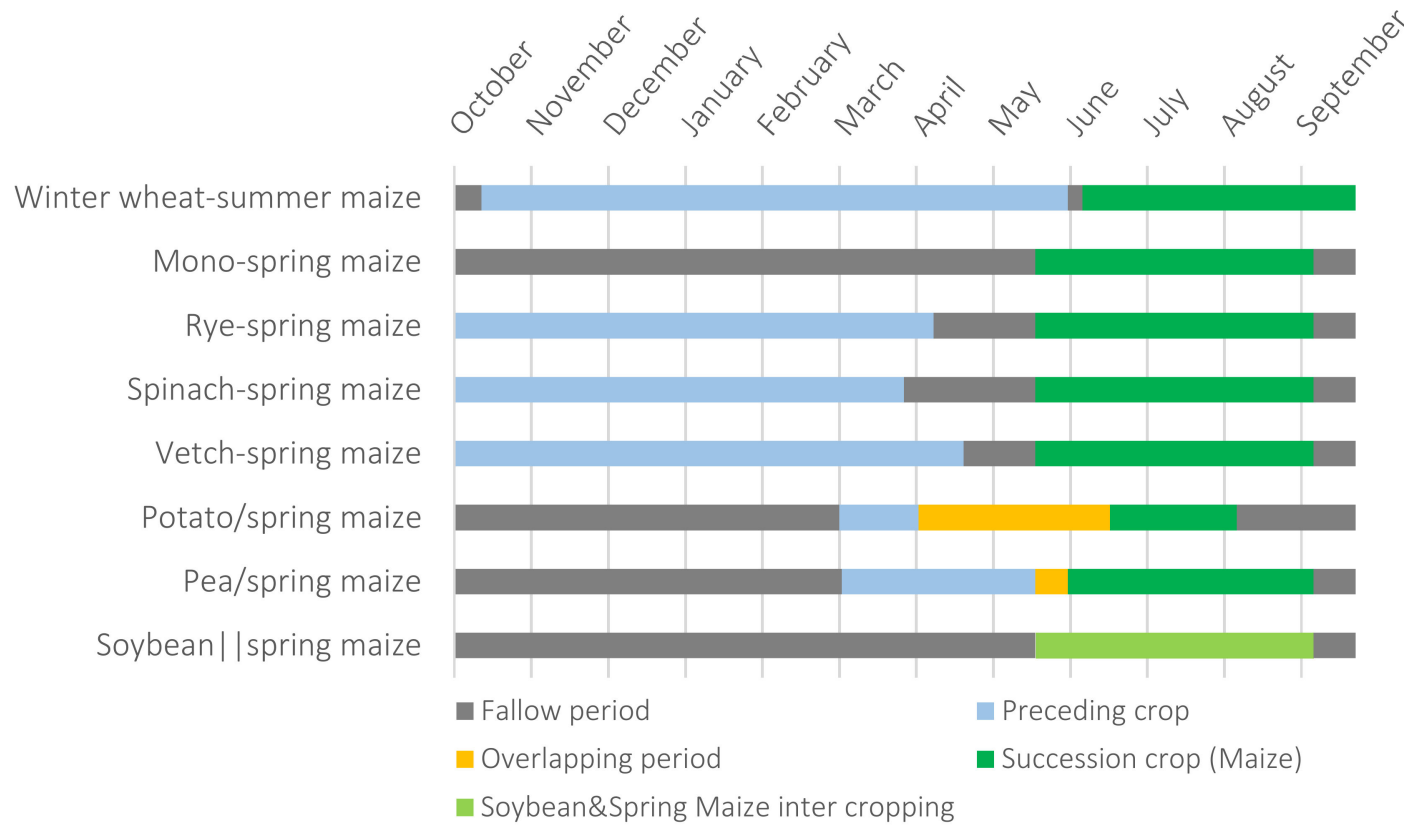

Figure 1. Crop seeding and harvest date and the span of growth. 


\subsection{Study Area}

The study was sited at the China Agricultural University experimental station in Wuqiao County $\left(37^{\circ} 41^{\prime} \mathrm{N}, 116^{\circ} 37^{\prime} \mathrm{E}\right)$ of the Hebei Province, China. The weather data were collected from Wuqiao weather station, which was close to the experimental station. The study area had a temperate sub humid-arid monsoon climate. The average daily temperature was $13^{\circ} \mathrm{C}$. The average annual sunlight was $2326 \mathrm{~h}$. The long-term average rainfall was $572 \mathrm{~mm}$, but it would fluctuate remarkably between years. The precipitation could be less than $400 \mathrm{~mm}$ in drought years and more than $800 \mathrm{~mm}$ in flood years. The distribution of precipitation within the year was also uneven. The rain was mainly concentrated in June to September when maize was growing. July and August precipitation could account for more than $70 \%$ of the total annual precipitation. In this study, three planting years have different precipitation characteristics. In the 2016 planting year, the total rainfall amount was $692 \mathrm{~mm}$, which was an average rainfall year. In the 2017 planting year, the total rainfall amount was $459 \mathrm{~mm}$, which was a drought year. The total amount of rainfall in the 2018 planting year was $813 \mathrm{~mm}$. It was a rainy year but with uneven rainfall due to the occurrences of heavy rainfall (115.4 mm on July 13 and $158.9 \mathrm{~mm}$ on August 14). Precipitation during the 2016-2018 planting years is attached in the Supplementary Materials. The annual surface evaporation ranged from 1100 to $1800 \mathrm{~mm}$.

\subsection{Water Consumption Calculation}

In order to make a more comprehensive and systematic accounting of cropping system water consumption, we combined fallow period evaporation and water consumption of agricultural materials (for example, pesticides, seeds, fertilizers, diesel, etc.) with green water, blue water and grey water in the water footprint. The sum of the green water and blue water represented the water requirement for crops. Green water referred to the crop water demand from the rainwater, blue water referred to the groundwater, in a nutshell. The evaporation of the fallow period was also considered since the assessment unit was the total water consumption of a planting year. The water demand of crops and the evaporation of the fallow period constituted infield water consumption. This evaluation also included the water that was consumed by making agricultural materials and grey water, so as to reveal the water consumption from the outfield. To sum up, the total water consumption included:

$$
\begin{gathered}
W=W_{\text {Crops Requirement }}+W_{\text {Fallow Evaporation }}+W_{\text {Agricultural Materials }}+W_{\text {Pollution Used }} \\
W_{\text {Crops consumption }}=W_{\text {green }}+W_{\text {blue }}
\end{gathered}
$$

where $W$ is the total water consumption of the whole cropping system $\left(\mathrm{m}^{3} / \mathrm{ha}\right), W_{\text {Crops Requirement }}$ is the sum of crop water requirements involved in the cropping system $\left(\mathrm{m}^{3} / \mathrm{ha}\right), W_{\text {Fallow Evaporation }}$ is fallow period soil evaporation $\left(\mathrm{m}^{3} / \mathrm{ha}\right), W_{\text {Agricultural Materials }}$ is the sum of the water consumption for producing agricultural materials used in crop production $\left(\mathrm{m}^{3} / \mathrm{ha}\right) . W_{\text {Pollution }}$ Used is the water demand $\left(\mathrm{m}^{3} / \mathrm{ha}\right)$ to dilute pollutants to the highest acceptable concentration for the natural environment, also named grey water footprint. $W_{\text {green }}$ is the green water footprint. $W_{\text {blue }}$ is the blue water footprint.

\subsubsection{Crops' Water Requirement}

Crops' water consumption numerically equals the crops' water requirement and it was influenced by climate. So, we separately calculated each of them by planting year. Crop water requirement refers to the amount of water that the crop consumed during the whole growth period under the appropriate soil water and fertility levels, which is consistent with the evapotranspiration of the crop in the field [40]. CROPWAT 8.0 software, developed by Martin Smith of the Food and Agriculture Organization of the United Nations (FAO) in Rome, Italy, was used to calculate crop water requirements. CROPWAT has been widely used in the study of water requirements and irrigation systems for a variety of crops. The calculation program is based on the single-crop coefficient method [41], and the detailed method can be seen in FAO Irrigation and drainage paper 56 [40]. 
In water footprint, in order to further analyze the constitution of crop water requirement, it was divided into two parts by its resources: from rainfall and from irrigation (which refers to groundwater in the NCP). They were also named green water and blue water, respectively. The green water in crop water requirement was the sum of the effective rainfall during each growth stage (according to CROPWAT 8.0 rules; a ten-day period was a stage). The effective rainfall during crop growth can be output by CROPWAT 8.0. If the effective rainfall within a ten-day period was greater than the crop evapotranspiration, then the rainfall actually utilized by the crop was as same as the crop evapotranspiration [42].

$$
P_{\text {use (dec) }}=\operatorname{Min}\left(P_{e f f(d e c)}, E T_{c(d e c)}\right)
$$

where $P_{\text {use (dec) }}(\mathrm{mm})$ is the effective rainfall used by crops within a ten-day period, $P_{\text {eff(dec) }}(\mathrm{mm})$ is the effective precipitation of a ten-day period, $E T_{c(d e c)}(\mathrm{mm})$ is the evapotranspiration of crops within a ten-day period.

Green water is the sum of the rainfall used during the period of crop growth:

$$
W_{\text {green }}=\sum_{1}^{n} P_{\text {use }(\text { dec })}
$$

where $W_{\text {green }}(\mathrm{mm})$ represents the total amount of green water in the whole growth period of the crop, $\mathrm{n}$ represents the number of ten-day periods a crop has passed through in its life.

The blue water in crop water requirement refers to the irrigation (groundwater) demand during the crop growth to make up for the need which has not met by rainfall. So, the difference between crop water requirement and used effective rainfall is the amount of irrigation water required at each growth stage, and no irrigation is required if the effective rainfall during the period is greater than or equal to the crop water requirement.

$$
I_{\text {req }(d e c)}=E T_{c(d e c)}-P_{u s e(d e c)}
$$

where $I_{r e q(d e c)}(\mathrm{mm})$ is the amount of irrigation needed in the ten-day period, $E T_{c(\mathrm{dec})}(\mathrm{mm})$ is the evapotranspiration of crops within the ten-day period. $P_{\text {use }(\mathrm{dec})}(\mathrm{mm})$ is the effective rainfall used by crops within the ten-day period.

The total amount of blue water is equal to the sum of irrigation water requirements at each growth stage.

$$
W_{\text {blue }}=\sum_{1}^{n} I_{\text {req }(\text { dec })}
$$

$W_{\text {blue }}$ represents the total amount of blue water in the whole growth period of the crop, $\mathrm{n}$ represents the number of ten-day periods a crop has passed through in its life.

Since there are four kinds of cropping systems: the mono-cropping, rotation cropping, relay cropping and intercropping systems in this study, which have different relationship between crops, it is necessary to calculate the single crop water requirement, respectively, then add them together by different rules for a system's water requirement. The specific calculation method and relevant data can be seen in the Supplementary Materials. Please note that the measurements need to be transferred into $\mathrm{m}^{3} /$ ha at the end.

\subsubsection{Fallow Period Soil Evaporation}

After crops have been harvested, soil evaporation should also be included in cropping system water consumption since the evaluation unit was a completed planting year. It was also influenced by climate. The specific calculation method can be found in FAO Irrigation and drainage paper 56 [40]. Please note that the measurements need to be transferred into $\mathrm{m}^{3} /$ ha at the end. 


\subsubsection{Agricultural Materials Water Consumption}

Water consumption of input materials was converted by using relevant parameters in the life cycle assessment database. All data of agricultural materials input were obtained from experimental records. The details are shown in the Supplementary Materials.

\subsubsection{Grey Water}

The inputs (such as fertilizers and pesticides) would pollute the environment, causing eutrophication and ecological toxicity of water bodies, and ultimately have potential impacts on the environment and human health through surface and underground runoff. In order to mitigate the negative effect, extra water is needed to dilute those chemicals to the maximum concentration that the water body can afford [43]. This is the grey water demand. In the case of multiple pollutants in the same water body, the water demand for diluting these pollutants is not accumulated; the final grey water demand is determined by the pollutant of the largest diluting water demand. Nitrogen and phosphorus are the biggest sources of non-point source pollution in crop production. Pollution of water caused by pesticides and other chemical inputs is not considered in this study. In general, the proportion of nitrogen fertilizer application is higher than that of phosphate fertilizer, and the loss is relatively high. So, in this study, grey water is numerically equal to the water demand of diluting leaching nitrogen to the natural concentration in water $[44,45]$.

The critical dilution volume method is usually used to calculate the grey water demand:

$$
\begin{gathered}
W_{\text {Pollution Used }}=\frac{L_{p}}{C_{\max }-C_{\text {nat }}} \\
L_{p}=F_{N} \cdot\left(l_{\alpha}+l_{\beta}\right)
\end{gathered}
$$

where $W_{\text {Pollution } \text { Used }}\left(\mathrm{m}^{3} / \mathrm{ha}\right)$ is grey water demand, $L_{p}(\mathrm{~kg})$ is the amount of pollutants into the water caused by each hectare of cultivated land, $C_{\max }\left(\mathrm{kg} / \mathrm{m}^{3}\right)$ is the concentration of the maximum pollutant that the water body can afford and $C_{\max }($ Nitrogen $)=3.1 \mathrm{mg} / \mathrm{L} ; C_{n a t}\left(\mathrm{~kg} / \mathrm{m}^{3}\right)$ is the natural concentration of the pollutant in water, $C_{\text {nat }}($ Nitrogen $)=1.5 \mathrm{mg} / \mathrm{L} . F_{N}(\mathrm{~kg} / \mathrm{ha})$ is the annual nitrogen requirement of cropping the system, $l_{\alpha}$ is the total nitrogen coefficient of fertilizer lost in the form of underground leaching, $l_{\beta}$ is the total nitrogen coefficient of fertilizer lost in the form of surface runoff. These specific data can be seen in Supplementary Materials.

\subsection{Food Supply Capacity}

In this study, the food supply ability of each cropping system was represented by the number of people that its annual yield could sustain. Since we were concerned most with the groundwater utilization efficiency, the unit water cost of a single person was calculated by dividing the blue water footprint by the number of people the cropping system can feed per year per hectare.

$$
\begin{gathered}
N=\frac{\sum_{i}\left(\text { yield }_{i} \cdot \text { calori }_{i} \cdot 10\right)}{\text { calorie }_{p} \cdot 365} \\
U C=\frac{\overline{W_{\text {blue }}}}{n}
\end{gathered}
$$

where $N$ is the number of people, yield $_{i}$ is the crop yield or biomass $(\mathrm{kg} / \mathrm{ha})$, calorie $e_{i}$ is the amount of the calories people obtain from a unit mass crop $(\mathrm{kcal} / 100 \mathrm{~g}), 10$ is the unit conversion coefficient, calorie $\mathrm{p}$ is quantity of heat (kcal/day)that the human daily basic metabolism consumes - here we used 25-year-old man's daily basic metabolism as the standard, 365 is the number of days in a year. For forage crops, such as rye, the human available calories are converted to 15 percent because of the energy lost from livestock to human. UC is the unit water cost of feeding a single person $\left(\mathrm{m}^{3} /\right.$ person), $\bar{W}_{\text {blue }}$ is the average of the blue water footprint of the cropping system of three planting years $\left(\mathrm{m}^{3} / \mathrm{ha}\right)$. 
Crop yields (yield of maize, soybean, and pea were grain yield; yield of potato was economic yield, yield of rye and spinach were fresh aboveground biomass) were obtained from experimental records. The calorie for various crops was derived from the Chinese Food Composition 2017 and the database of U.S. Department of Agriculture. The specific information is shown in Table 1.

Table 1. Crop yield and unit calories of different cropping systems.

\begin{tabular}{|c|c|c|c|c|}
\hline \multirow{2}{*}{ Systems } & \multirow{2}{*}{ Crops } & Average Yield & Unit of Calories & \multirow{2}{*}{$\begin{array}{c}\text { Human Consumed Calories } \\
\text { kcal/Day }\end{array}$} \\
\hline & & kg/ha·Year & kcal/100 g & \\
\hline \multirow{2}{*}{$\begin{array}{l}\text { Winter wheat- } \\
\text { summer maize }\end{array}$} & wheat & 8787.07 & 352 & \multirow{13}{*}{$\begin{array}{l}1609 \\
\text { Take a } 25 \text {-year-old male with a } \\
\text { height of } 170 \mathrm{~cm} \text { and a weight of } \\
75 \mathrm{~kg} \text { as an example. }{ }^{3}\end{array}$} \\
\hline & maize & $11,044.39$ & 335 & \\
\hline \multirow[t]{2}{*}{ Mono-spring maize } & maize & $10,018.24$ & 335 & \\
\hline & rye $^{1}$ & $12,139.50$ & 60.21 & \\
\hline Rye-spring maize & maize & 9974.55 & 335 & \\
\hline \multirow{2}{*}{ Spinach-spring maize } & spinach & $67,833.33$ & 24 & \\
\hline & maize & 9939.09 & 335 & \\
\hline \multirow[t]{2}{*}{ Vetch-spring maize } & maize & $10,439.62$ & 335 & \\
\hline & potato & $24,132.41$ & 76 & \\
\hline Potato/spring maize & maize & 8693.93 & 335 & \\
\hline \multirow{2}{*}{ Pea/spring maize } & pea $^{2}$ & 2031.72 & 364 & \\
\hline & maize & $10,113.82$ & 335 & \\
\hline Soybean\|spring maize & maize & 9816.85 & 335 & \\
\hline
\end{tabular}

Note: ${ }^{1}$ : The rye was not included in food terms, so we did not obtain calorie information from the above database. We calculated its calories based on following nutrient information: the human body can produce about 4 kilocalories ( $\mathrm{kcal}$ ) by per gram of protein or carbohydrate, and 9 kilocalories per gram of fat. Rye contains $9.27 \%$ crude protein of its dry matter weight, and crude fat accounts for $2.57 \%$. Rye's fresh to dry ratio was 2.3 [46]. 2: The information for peas was cited from United States Department of Agriculture (USDA) Food Data Central (the entry was "Peas, green, split, mature seeds, raw"). ${ }^{3}$ : This information was cited from: http://www.boohee.com/assessment/bmr?submit_type=submit.

\section{Results}

\subsection{The Total Water Consumption of Multiple Cropping Systems}

The results indicated that the winter wheat-summer maize system had the largest water consumption (Figure 2). On average, the total water consumption of the winter wheat-summer maize system was $16,585 \mathrm{~m}^{3} /$ ha, followed by the potato/spring maize, spinach-spring maize, rye-spring maize, vetch-spring maize, pea/spring maize, soybean||spring maize and mono-spring maize cropping system. The other cropping systems' water consumptions were $86.45 \%, 83.45 \%, 78.55 \%, 75.58 \%, 71.58 \%$, $54.12 \%, 48.04 \%$ of the winter wheat-summer maize system, respectively.

From the perspective of its components, crop water requirement and grey water were two major water consuming elements. Surprisingly, grey water could account for $28.48-51.04 \%$ of the system's total water consumption, especially in the spinach-spring maize system which was $51.04 \%$. It was the high demand for grey water that increased the total water consumption of the spinach-spring maize system. The crops actually used much less water (Figure 2). The results revealed that grey water was an important water consuming aspect outside of the farmland. Reducing fertilizer input, improving the utilization efficiency of fertilizer and reducing wastage are also important parts of water saving.

\subsection{The Infield Water Consumption in Multiple Cropping Systems}

The infield water consumption was the sum of the green water and blue water in the crop water requirement and the soil evaporation of the fallow period, which were strongly affected by the crop characteristics and the weather. The results showed the highest infield water consuming system was the winter wheat-summer maize system, except for potato/spring maize system in the 2017 planting year. Beside the spring maize mono-cropping system, the soybeans\|spring maize inter-cropping system, pea/spring maize relay cropping system and spinach-spring maize rotation cropping system (Figure 3) were the three lowest water consuming multiple systems. 


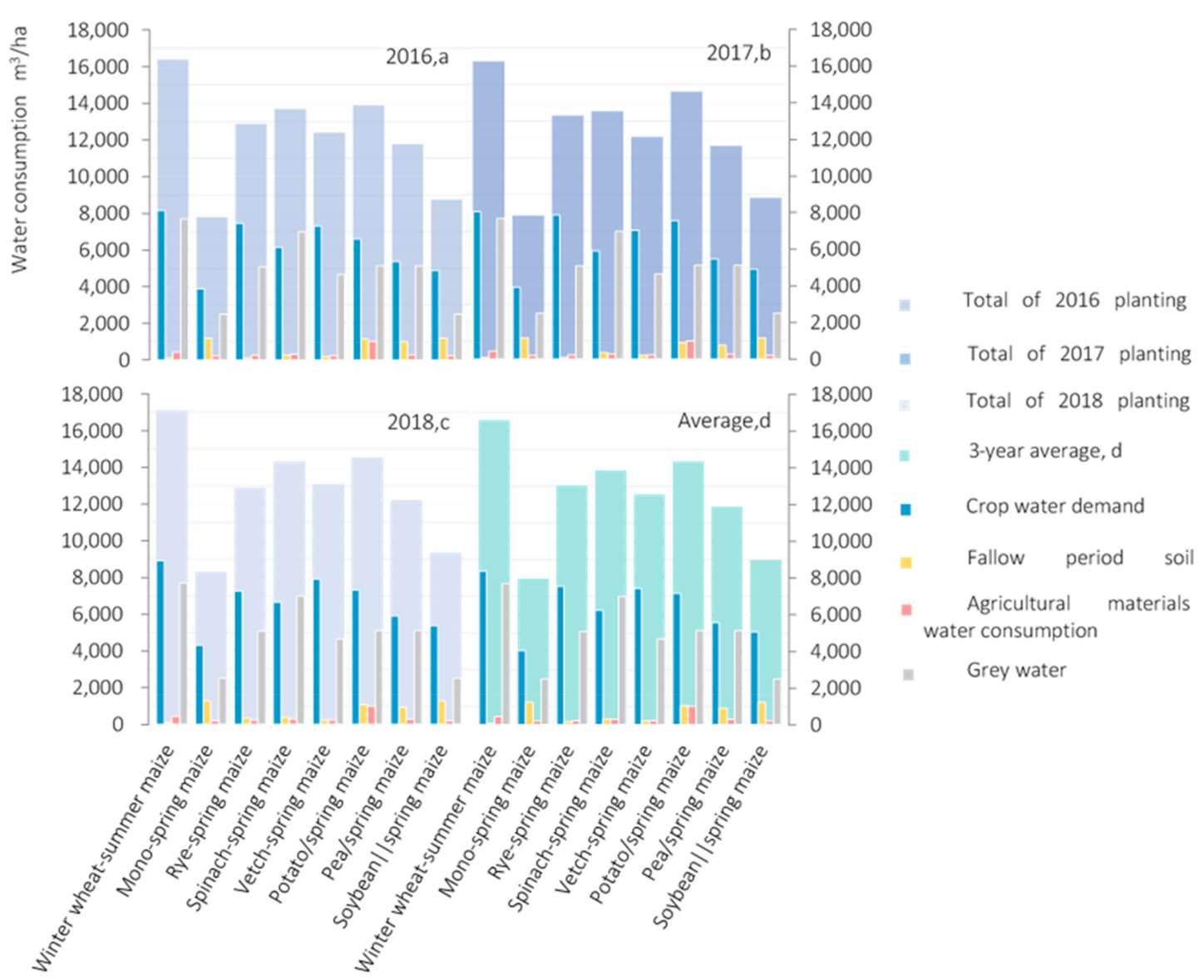

Figure 2. The water footprint and its composition of multiple cropping systems.

Analyzing the composition of infield water consumption could probably reveal the best precipitation-coupled cropping system involved in this study. The system with a higher proportion of green water represented a higher degree of synchronization between rainfall and crop growth. The most important find was that, on the other side, those systems consumed less blue water which referred to groundwater here. For the average result, the blue water of six alternative cropping systems was $84.1-42.4 \%$ of the winter wheat-summer maize system, and that of the mono-spring maize system was only $28.4 \%$. Compared with the winter wheat-summer maize system, except for potato/spring maize system in the 2017 planting year, all other systems in the three planting years consumed less groundwater. In other words, multiple cropping systems could save water under different precipitation conditions. Among them, the pea/spring maize relay cropping system and soybean||spring maize inter-cropping system were the two lowest blue water demand systems, with blue water accounting for $38.2 \%$ and $36.7 \%$ of the annual infield water consumption, respectively. However, soil evaporation of the fallow period in these two systems was also prominent, accounting for $13.9 \%$ and $19.4 \%$ of 4 annual infield water consumption, respectively. The fallow period in the mono-cropping, intercropping and relay cropping systems was significantly longer than that in the double cropping or rotation cropping systems. So, the soil evaporation of them was higher, which seemed to be a waste. Among rotation cropping systems, the spinach-spring maize system had the lowest annual water consumption. This was because spinaches had the lowest water requirement, and the spring maize had the obvious advantage of absorbing rainfall (Figure 4) so that the blue water demand of this system was less, $3427 \mathrm{~m}^{3} /$ ha, which was just $20.8 \%$ higher than soybean-spring maize system. At the same time, the evaporation during the fallow period was $326.2 \mathrm{~m}^{3} /$ ha, whereas that of pea/spring maize was $896.8 \mathrm{~m}^{3} /$ ha and that of soybean\|spring maize was $1215.5 \mathrm{~m}^{3} /$ ha. Totally, the annual infield water 
consumption of the spinach-spring maize system was only 1.3-4.6\% higher than that of the pea/spring maize and soybean||spring maize systems, but more water was used for crop growing. Overall, the spinach-spring maize system was better than the pea/spring maize and soybean||spring maize system in terms of water saving.

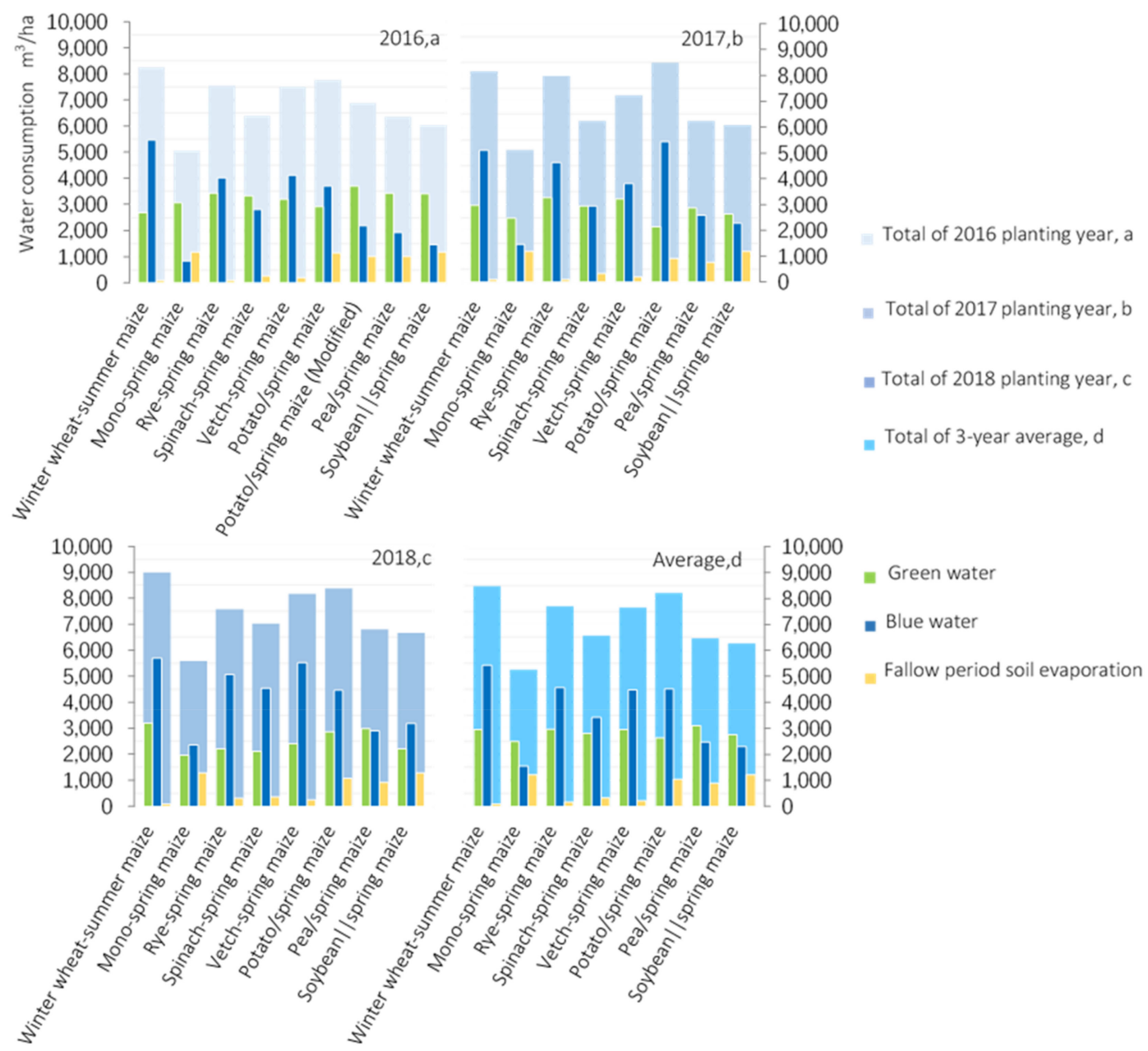

Figure 3. The infield water consumption and its composition of cropping systems (a-d).

In addition, the result not only revealed the water consumption level of each cropping system, but also pointed out the optimization scheme of the cropping system which had high water consumption. The potato/spring maize relay cropping system was the highest infield water consumption system among the six alternative cropping systems (see Figure 3). Because the growing period of spring maize in this system did not match with the precipitation period, its irrigation demand was large (see Figure 4 , comparing spring maize II and spring maize III). However, if the sowing time could be adjusted, the water consumption structure of the potato/spring maize system would be optimized. For example, if the spring maize sowing time in the 2016 planting year had been adjusted to the middle of May, like with spring maize III, the total infield water consumption would reduce $11.38 \%$, green water increase by $26.92 \%$, blue water requirement fall 41.09\% (see Figure 3, 2016,a, Potato/spring maize and Potato/spring maize(modified)). For other cropping systems, it was also promising to achieve a better water saving effect after appropriate adjustment of the present management. 


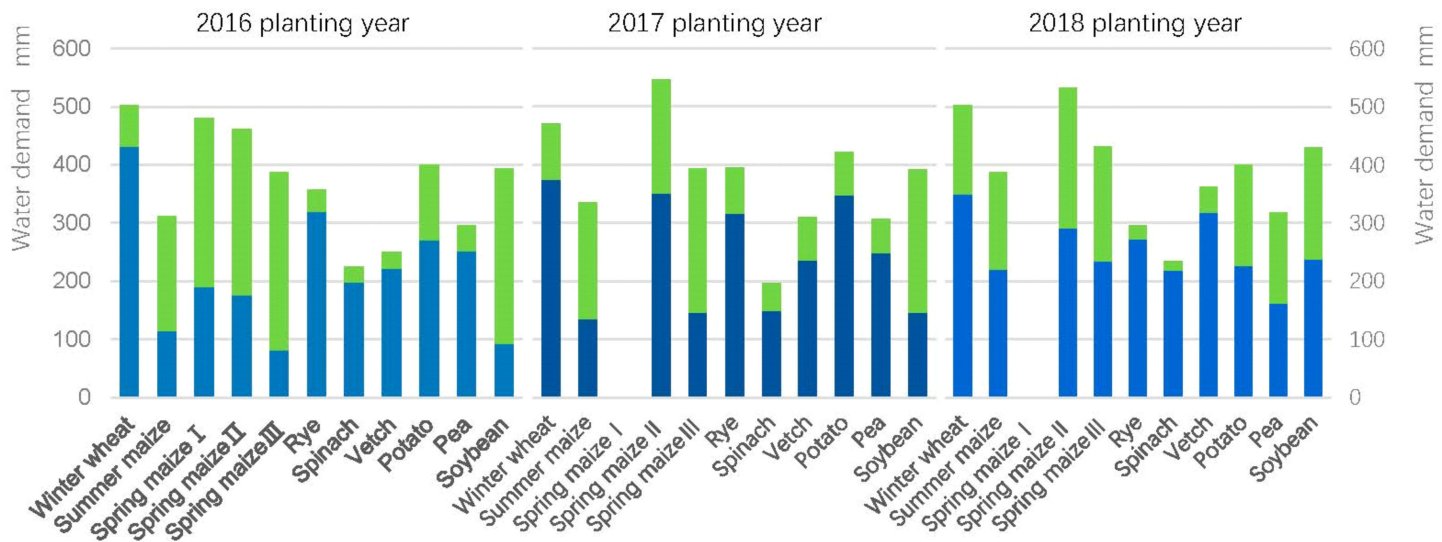

Figure 4. The water requirement and its composition of crops. Spring maize I represents the maize planted in vetch-spring maize plots in the 2016 planting year, the sowing date was 9 April. Its sowing date in the 2017 and 2018 planting years was the same as spring maize III. Spring maize II is the maize of the potato/spring maize cropping system, the sowing date was usually earlier than the other spring maize. Spring maize III represents the maize in other cropping systems, they had the same sowing date in the middle of May.

\subsection{The Food Supply Capacity of Multiple Cropping Systems}

Since the North China Plain is one of the vital basements of China's food production, the food supply capacity should be considered when selecting alternative cropping systems. The results showed that 1 hectare of the winter wheat-summer maize system could produce enough food energy to feed 116 people per year on average, the spinach-spring maize, potato/spring maize, pea/spring maize, vetch-spring maize, rye-spring maize, mono-spring maize and soybean||spring maize cropping systems, could feed 84, 81, 70, 60, 58, 57, 56 people, respectively (see Figure 5). They had $73.0-48.4 \%$ of the winter wheat-summer maize system's supply capacity. Regarding the blue water consumption on feeding one single person, the spinach-spring maize, pea/spring maize and soybean||spring maize systems had higher efficiency than that of the winter wheat-summer maize system. Other systems need more water to feed one person (see Figure 5). On the whole, the spinach-spring maize system probably will become a replacement system for the North China Plain after the grey water demand has been reduced.

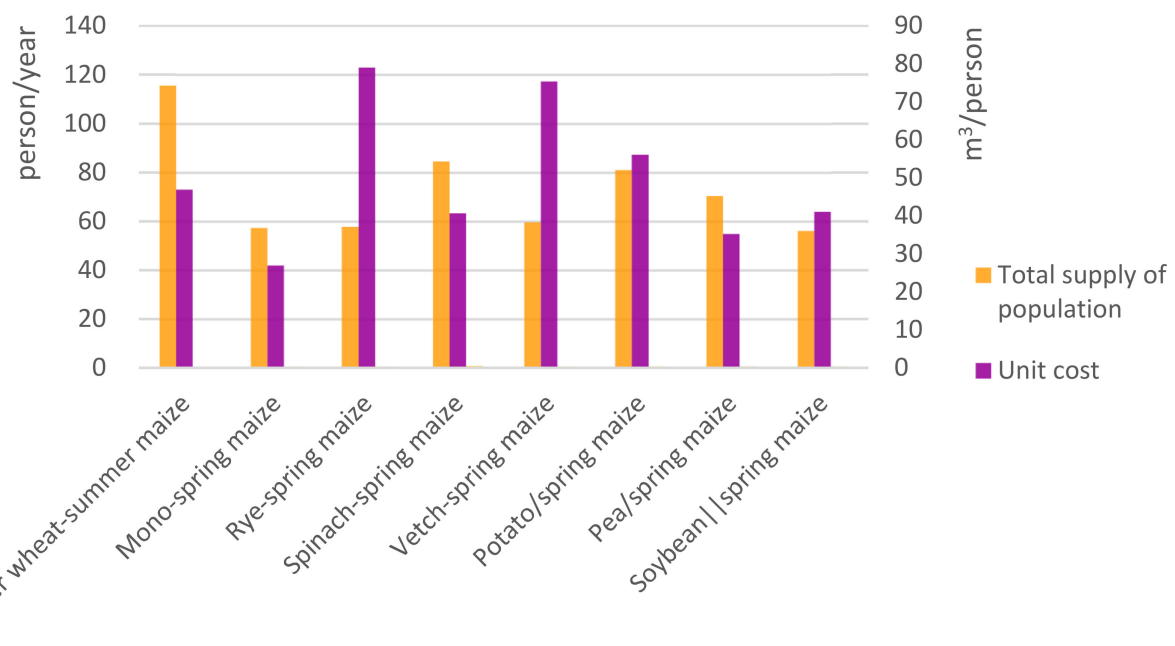

Figure 5. The feeding population of multiple cropping systems and their water consumption for a single person. In the soybean-spring maize cropping system, soybeans were treated as green manure, which did not have contribution to the yield. However, maize yield had been slightly affected. 


\section{Discussion}

\subsection{The Relationship Between Water Saving and Food Security}

In this study, the results showed that the winter wheat-summer maize system had the highest water consumption (see Section 3.1 and Figure 2), but also had the highest feeding capacity and not a bad efficiency (see Section 3.3 and Figure 5). It seems that the conflict between water saving and food security is intricate and not easy to break.

To break the logjam, we need to know which is more urgent: saving water or food security. It is more urgent to solve the groundwater problem in the North China Plain. At present, the groundwater overexploitation is very serious. If the subsidence become worse, people will face the situation of losing their lands and homes. By contrast, if the region's groundwater level can stop declining by through the implementation of water-saving cropping systems, a 30\% reduction in calorie-supply capacity is acceptable in our view.

Policy makers should rationalize the distribution of cropping systems and partially replace the winter wheat-summer maize cropping system in order to ensure the balance between water saving and food security. Compared with the winter wheat-summer maize system, all other alternative systems have more or less water-saving advantages, but they also have yield loss. So, our recommendation is to partially replace the winter wheat-summer maize system in areas where groundwater is extremely scarce. We support the production of adapted crops in suitable environments and the implementation of sustainable and diversified cropping systems in the region.

We also know that future food security is not only reflected in calories, but also in the consideration of diversity nutrition. Wheat and maize are cereal crops, which contain much more starch than the vegetables, so there is no doubt that they can offer more calories, whereas vegetables contain less calories, but they provide more vitamins and minerals, which are also vital for people's daily diet. The magnitude and diversity of China's agricultural production has expanded as its population becomes wealthier and more urbanized. Chinese taste in food has shifted with sharply increasing demands for meat, dairy, and fresh fruit and vegetables [47]. So, the agriculture production will not only focus on grain in the future, but will also need more vegetables and forage resources for multiple sustainable goals. The spinach-spring maize, pea/spring maize, potato/spring maize soybean||spring maize systems could provide the nation with grains and vegetables; the rye-spring maize and vetch-spring maize systems could supply the forage grass for the cattle. In addition, some of them can reduce water consumption, especially groundwater, and also have better groundwater utilization efficiency than the traditional cropping system (see Section 3.3 and Figure 5).

If the above points can be considered, reducing water consumption without compromising food security through new cropping systems in North China Plain is still promising.

\subsection{The Application of Water Footprint in Cropping Systems}

In existing water footprint studies, most of them focused on a single crop [48-51], that may be related to the original definition of the water footprint [33], referring to the amount of water resources required for a product or service. In recent years, Hoekstra had also applied the water footprint method to evaluate different farmland management systems [52]. This study was trying to expand the application of the water footprint further onto multiple cropping systems. Different from a single crop, the multi-cropping system involved the problems of time, space and multiple crops, which demanded that we to consider the relationship between crops and the distribution of crops in time and space. This was particularly evident when calculating the water requirements of cropping systems. For the rotation cropping system, we added the green and blue water of the two crops directly because there was no overlapping period between the preceding and succeeding crops. For relay cropping and inter-cropping systems, we had to consider the comprehensive evapotranspiration of the two crops as a whole while we calculating the green water and blue water of the overlapping period of the preceding and succeeding crops. This could not be achieved in CROPWAT 8.0 directly. We offered 
a method to adjust the result based on crop density (The specific calculation process can be seen in Supplementary Materials). However, as there was no similar practice in previous studies, the accuracy cannot be confirmed. It is expected that researchers can correct the results by actual measurement in the future, with the breakthrough of technology and the simplification of measurement methods.

\subsection{Future Work}

This study still has some extra work which needs to be done.

First, as we mentioned above, we also believed that to only use calories as the indicator for food supply analysis was not comprehensive enough. It is clear that cereals and staple crops are most efficient in terms of calories, while vegetables are not, but they provide more vitamins and minerals; thus, a more diverse measure should be taken. Moreover, the income of each cropping system should also be considered so as to make the evaluation frame more complete.

Second, we need to improve the fine management of the planting system. We found that the present management of some cropping systems may not the best way to conduct this management. There still was a considerable potential to reduce water consumption. For example, the potato/spring maize relay cropping system was the system with the highest infield water consumption among the six alternative cropping systems, because the growing period of spring maize in this system did not match with the precipitation period. However, if the spring maize sowing time in the 2016 planting year had been adjusted to the middle of May, the total infield water consumption would reduce by $11.38 \%$, green water increase by $26.92 \%$, blue water requirement fall $41.09 \%$. For other cropping systems, it was also possible to achieve large water savings after appropriate adjustment of the present management.

\section{Conclusions}

In order to find one or several substitutions to mitigate the water pressure caused by the winter wheat-summer maize cropping system in the North China Plain, we compared six alternative cropping systems by combined water consumption and their food supply capacity. Regarding the system total water consumption, potato/spring maize, spinach-spring maize, rye-spring maize, vetch-spring maize, pea/spring maize, soybean||spring maize and mono-spring maize cropping systems can achieve $14-52 \%$ of the water consumption of the winter wheat-summer maize system. For the groundwater that we were most concerned with, the spinach-spring maize, pea/spring maize, soybean||spring maize systems showed a higher degree of synchronization between crop growth period and rainfall, the advantage that could reduce the use of groundwater by $36.8 \%, 54.4 \%$ and $57.6 \%$. Regarding food supply efficiency, the spinach-spring maize, pea/spring maize, soybean||spring maize systems showed a better feeding efficiency than the winter wheat-summer maize system. All in all, our results suggest that the spinach-spring maize system is a promising alternative cropping system, which can reduce water consumption and also have better groundwater utilization efficiency than the traditional cropping system.

This study was also trying to expand the application of the water footprint further onto multiple cropping systems and trying to set up a combined and useful framework for the evaluation of multiple cropping systems. Water shortage is a world-wide crisis. The North China Plain is also facing a severe groundwater overexploitation problem. We hope that the scientific community know that China is trying to mitigate this crisis by the shifting cropping system from a water-consuming one to water-saving ones. We hope our experience and work could offer a method that is useful for other researchers who are facing the same problem in other regions.

It is not easy to balance water saving and food security. For our study area, the North China Plain, it is more urgent to solve the groundwater problem. Policy makers should rationalize the distribution of cropping systems and partially replace the winter wheat-summer maize cropping system. Future food security should not only focus on calories, but also consider nutrition diversity. According to our results, the alternative cropping systems do have food calories loss, however they have water saving potential and can provide other diversity nutrients along with the increasing need. 
So, reducing the water footprint without compromising food security through new cropping systems in North China Plain is still promising.

Supplementary Materials: The following are available online at http://www.mdpi.com/2073-4441/12/10/2946/s1. Figure A1: Precipitation during the planting year 2016 to 2018, Table B1: The length of crop development stages and crop coefficients, Table B2: The calculation of the water requirement of the Potato/Maize system, Table B3: The calculation of the water requirement of the Pea/Maize system, Table B4: The calculation of the water requirement of the Soybean||Maize system, Table C1: The input of agricultural capital goods in different cropping systems, Table C2: The water consumption parameters of the agricultural means of production, Table D1: Total nitrogen loss rates of different cropping systems, Table E1: The total water consumption and its composition of multiple cropping systems, Table E2: The infield water consumption and its composition of multiple cropping systems, Table E3: The crop's water requirement and its composition, Table E4: The feeding population of the cropping system and its water consumption of a single person.

Author Contributions: Conceptualization, Y.C. and P.S.; methodology, J.Y.; software, J.Y.; validation, J.Y., J.C., Z.L., M.R., B.S.; formal analysis, J.Y.; investigation, J.Y., J.C., Z.L., M.R., B.S.; resources, Y.C., P.S.; data curation, J.Y., J.C., Z.L., M.R., B.S.; writing—original draft preparation, J.Y.; writing-review and editing, J.C., Y.C.; visualization, J.Y.; supervision, Y.C., P.S.; project administration, Y.C.; funding acquisition, Y.C., P.S. All authors have read and agreed to the published version of the manuscript.

Funding: This work was supported by National Key Research and Development Program of China (Grant No. 2016YFD0300210 and 2016YFD0300203).

Acknowledgments: Many thanks to Lin Wang. Special thanks to Sijia Chen.

Conflicts of Interest: The authors declare no conflict of interest.

\section{References}

1. Falkenmark, M. Growing water scarcity in agriculture: Future challenge to global water security. Philos. Trans. R. Soc. A Math. Phys. Eng. Sci. 2013, 371, 20120410. [CrossRef]

2. Kummu, M.; Ward, P.J.; de Moel, H.; Varis, O. Is physical water scarcity a new phenomenon? Global assessment of water shortage over the last two millennia. Environ. Res. Lett. 2010, 5, 034006. [CrossRef]

3. Oki, T.; Kanae, S. Global hydrological cycles and world water resources. Science 2006, 313, 1068-1072. [CrossRef]

4. Vörösmarty, C.J.; Green, P.; Salisbury, J.; Lammers, R.B. Global water resources: Vulnerability from climate change and population growth. Science 2000, 289, 284-288. [CrossRef]

5. Wada, Y.; van Beek, L.P.H.; Bierkens, M.F.P. Modelling global water stress of the recent past: On the relative importance of trends in water demand and climate variability. Hydrol. Earth Syst. Sci. Discuss. 2011, 8, 7399-7460. [CrossRef]

6. Wada, Y.; van Beek, L.P.H.; Viviroli, D.; Drr, H.H.; Weingartner, R.; Bierkens, M.F.P. Global monthly water stress: 2. Water demand and severity of water stress. Water Resour. Res. 2011, 47. [CrossRef]

7. Schewe, J.; Heinke, J.; Gerten, D.; Haddeland, I.; Arnell, N.W.; Clark, D.B.; Dankers, R.; Eisner, S.; Fekete, B.M.; Colón-González, F.J.; et al. Multimodel assessment of water scarcity under climate change. Proc. Natl. Acad. Sci. USA 2014, 111, 3245-3250. [CrossRef]

8. Alcamo, J.; Flörke, M.; Märker, M. Future long-term changes in global water resources driven by socio-economic and climatic changes. Hydrol. Sci. J. 2007, 52, 247-275. [CrossRef]

9. Gosling, S.N.; Arnell, N.W. A global assessment of the impact of climate change on water scarcity. Clim. Chang. 2016, 134, 371-385. [CrossRef]

10. Cao, G. Evaluation of Groundwater System in the North China Plain Using Groundwater Modeling; University of Geosciencces: Beijing, China, 2013.

11. Zheng, C.; Liu, J.; Cao, G.; Kendy, E.; Jia, Y. Can China Cope with Its Water Crisis? Perspectives from the North China Plain. Groundwater 2010, 48, 350-354. [CrossRef]

12. Hwang, C.; Yang, Y.; Kao, R.; Han, J.; Shum, C.K.; Galloway, D.L.; Sneed, M.; Hung, W.C.; Cheng, Y.S.; Li, F. Time-varying land subsidence detected by radar altimetry: California, Taiwan and north China. Sci. Rep. 2016, 6, 1-12. [CrossRef] [PubMed]

13. Zhao, Y.; Zhu, Y.; Lin, Z.; Wang, J.; He, G.; Li, H.; Li, L.; Wang, H.; Jiang, S.; He, F.; et al. Energy reduction effect of the South-To-North Water Diversion Project in China. Sci. Rep. 2017, 7, 1-9. [CrossRef] [PubMed] 
14. National Bureau of Statistics of China China Statistical Yearbook 2008; National Bureau of Statistics of China: Beijing, China, 2008.

15. Zhang, G.; Liu, Z.; Fei, Y.; Lian, Y.; Yan, M.; Wang, J. The relationship betwen the distribution of irrigated crops and the supply capability of regional water resources in North China plain. Acta Geosci. Sin. 2010, 31, $17-22$.

16. Xu, C.Y.; Singh, V.P. Evaluation of three complementary relationship evapotranspiration models by water balance approach to estimate actual regional evapotranspiration in different climatic regions. J. Hydrol. 2005, 308, 105-121. [CrossRef]

17. Chen, S.; Zhang, X.; Shao, L.; Sun, H.; Niu, J. A comparative study of yield, cost-benefit and water use efficiency between monoculture of spring maize and double crops of wheat-maize under rain-fed condition in the North China Plain. Chin. J. Eco Agric. 2015, 23, 535-543. [CrossRef]

18. Wang, D.; Wu, W.; Gu, S.; Meng, F.; Shi, Y. Water-saving effect under adjustment of cropping systems and optimization of water and nitrogen in high yield regions of North China. Trans. Chin. Soc. Agric. Eng. 2013, 29, 1-8. [CrossRef]

19. Yang, Y.; Watanabe, M.; Zhang, X.; Zhang, J.; Wang, Q.; Hayashi, S. Optimizing irrigation management for wheat to reduce groundwater depletion in the piedmont region of the Taihang Mountains in the North China Plain. Agric. Water Manag. 2006, 82, 25-44. [CrossRef]

20. Zhang, X.; Pei, D.; You, M. Field studies on optimum irrigation scheduling for winter wheat in the piedmont of Mt.Taihang. Shuili Xuebao 2001, 90-95. [CrossRef]

21. Liang, H.; Qin, W.; Hu, K.; Tao, H.; Li, B. Modelling groundwater level dynamics under different cropping systems and developing groundwater neutral systems in the North China Plain. Agric. Water Manag. 2019, 213, 732-741. [CrossRef]

22. Gao, M.; Luo, Q. Study on cropping structure optimization in region short of water-A case study of North China. J. Nat. Resour. 2008, 23, 204-210. [CrossRef]

23. Sun, Q.; Kröbel, R.; Müller, T.; Römheld, V.; Cui, Z.; Zhang, F.; Chen, X. Optimization of yield and water-use of different cropping systems for sustainable groundwater use in North China Plain. Agric. Water Manag. 2011, 98, 808-814. [CrossRef]

24. Xiao, D.; Shen, Y.; Qi, Y.; Moiwo, J.P.; Min, L.; Zhang, Y.; Guo, Y.; Pei, H. Impact of alternative cropping systems on groundwater use and grain yields in the North China Plain Region. Agric. Syst. 2017, 153, 109-117. [CrossRef]

25. Guo, B.; Tao, H.; Wang, P.; Knorzer, H.; Claupein, W. Water utilization of different cropping production systems in the North China Plain. J. China Agric. Univ. 2013, 18, 53-60.

26. Yan, P.; Chen, Y.; Zhang, X.; Tao, Z.; Yang, X.; Sui, P. Security of water-ecology and food under replacement of winter wheat-summer maize rotation with spring maize mono-cropping in Hebei Lowland Plains. Chin. J. Eco Agric. 2016, 24, 1491-1499. [CrossRef]

27. Li, J. Function of forage in animal husbandry in the farming region. Sichuan Anim. Vet. Sci. 2002, 29, $24-25$.

28. Pan, G.; Ouyang, Z.; Li, P. Cultivation pattern and development of quality forage in the North China Plian. Resour. Sci. 2007, 29, 15-20.

29. Shi, P.; Yang, D.; Zheng, Y.; Liang, M.; Dang, J.; Wang, G. Study on compound cropping systems of food and forage in North China Plain. Pratacultural Sci. 2015, 32, 2107-2113.

30. Zhang, M.; Sui, P.; Chen, Y.; Sun, Z.; Ma, L. Water consumption characteristics of alternative crop rotations in the piedmont of Mt.Taihang. Chin. Agric. Sci. Bull. 2011, 27, 251-257.

31. Zhou, Z. Benefit Assessment and Spatial Prediction of Green Mauring; China Agricultural University: Beijing, China, 2016.

32. Zhang, W.; Chen, Y.; Sui, P.; Gao, W.; Liu, H. Research of eco-economy on substitution planting patterns in the North China Plain. Chin. Agric. Sci. Bull. 2009, 25, 241-245.

33. Aldaya, M.M.; Chapagain, A.K.; Hoekstra, A.Y.; Mekonnen, M.M. The Water Footprint Assessment Manual: Setting the Global Standard; Routledge: Washington, DC, USA, 2012; ISBN 9781849712798.

34. Chapagain, A.K.; Hoekstra, A.Y. The water footprint of coffee and tea consumption in the Netherlands. Ecol. Econ. 2007, 64, 109-118. [CrossRef] 
35. Chapagain, A.K.; Hoekstra, A.Y. Virtual water trade: A quantification of virtual water flows between nations in relation to international trade of livestock and livestock products. In Proceedings of the Virtual Water Trade Proceedings of International Expert Meeting on Virtual Water Trade-Value of Water; UNESCO-IHE: Delft, The Netherlands, 2003; pp. 49-76.

36. Gai, L.; Xie, G.; Li, S.; Zhang, C.; Chen, L. A study on production water footprint of winter-wheat and maize in the North China Plain. Resour. Sci. 2010, 32, 2066-2071.

37. Sun, S.K.; Wu, P.T.; Wang, Y.B.; Zhao, X.N. The virtual water content of major grain crops and virtual water flows between regions in China. J. Sci. Food Agric. 2013, 93, 1427-1437. [CrossRef] [PubMed]

38. Lovarelli, D.; Bacenetti, J.; Fiala, M. Water Footprint of crop productions: A review. Sci. Total Environ. 2016, 548-549, 236-251. [CrossRef]

39. Cui, J.; Sui, P.; Wright, D.L.; Wang, D.; Sun, B.; Ran, M.; Shen, Y.; Li, C.; Chen, Y. Carbon emission of maize-based cropping systems in the North China Plain. J. Clean. Prod. 2019, 213, 300-308. [CrossRef]

40. Allen, R.; Pereira, L.; Raes, D.; Smith, M.; Allen, R.G.; Pereira, L.S.; Martin, S. Crop Evapotranspiration: Guidelines for Computing Crop Water Requirements; FAO Irrigation and Drainage Paper 56; FAO: Rome, Italy, 1998; Volume 56.

41. Smith, M. A Computer Program for Irrigation Planning and Management; FAO: Rome, Italy, 1992; Volume 46.

42. Lu, Y.; Liu, X.; Zhang, X. Research progress on water footprint in agricultural products. Chin. J. Appl. Ecol. 2015, 26, 3207-3214. [CrossRef]

43. Zarate, E. (Ed.) WFN Grey Water Footprint Working Group Final Report: A Joint Study Developed by WFN Partners; Water Footprint Network: Enschede, The Netherlands, 2010.

44. Xu, C. Case Studies of Water Footprinting in Agri-Food Sector; China Agricultural University: Beijing, China, 2014.

45. Chapagain, A.K.; Hoekstra, A.Y.; Savenije, H.H.G.; Gautam, R. The water footprint of cotton consumption: An assessment of the impact of worldwide consumption of cotton products on the water resources in the cotton producing countries. Ecol. Econ. 2006, 60, 186-203. [CrossRef]

46. He, H.; Li, Q.; Mao, H.; Chen, Y.; Jin, Z.; Sun, Z. Comprehensive evaluation of production performance and nutritional value of rye and highland barley. Heilongjiang Anim. Sci. Vet. Med. 2018, 156-159. [CrossRef]

47. Hawkins, J.; Ma, C.; Schilizzi, S.; Zhang, F. China's changing diet and its impacts on greenhouse gas emissions: An index decomposition analysis. Aust. J. Agric. Resour. Econ. 2018, 62, 45-64. [CrossRef]

48. Mekonnen, M.M.; Hoekstra, A.Y. The green, blue and grey water footprint of crops and derived crop products. Hydrol. Earth Syst. Sci. 2011, 15, 1577-1600. [CrossRef]

49. Huang, J. The Sustainable Use of Agricultural Water in Beijing Based on Water Footprinting; China Agricultural University: Beijing, China, 2013.

50. Chen, M.; Li, Y.; Wang, G.; Li, T.; Zhou, Y. Water footprint-based fractional programming model for regional crop planting structure optimization. J. Hydroelectr. Eng. 2017, 36, 22-30. [CrossRef]

51. Liu, C. Evaluation on utilization of water resources of food production in China. J. Huazhong Agric. Univ. Sci. Ed. 2017, 22-29.

52. Zhuo, L.; Hoekstra, A.Y. The effect of different agricultural management practices on irrigation efficiency, water use efficiency and green and blue water footprint. Front. Agric. Sci. Eng. 2017, 4, 185-194. [CrossRef]

Publisher's Note: MDPI stays neutral with regard to jurisdictional claims in published maps and institutional affiliations.

(C) 2020 by the authors. Licensee MDPI, Basel, Switzerland. This article is an open access article distributed under the terms and conditions of the Creative Commons Attribution (CC BY) license (http://creativecommons.org/licenses/by/4.0/). 